\title{
COLLECTION OF ZAKAT FOR CIVIL STATE EMPLOYEES ACCORDING TO ISLAMIC LAW AND LAW
}

\author{
Nurhadi \\ Islamic College (STAI) Al-Azhar Pekanbaru Riau \\ Email: alhadijurnal@gmail.com; alhadicentre@yahoo.co.id
}

\begin{abstract}
Then in 1998-1999 and 2001-2003 BAZNAS was formed with the Presidential Decree so that in 2011 the rule of zakat processing emerged namely Law Number 23 of 2011. Through this formal law the author will examine the terminology of amil zakat according to Islamic Law and Law. Amil zakat is a person who is involved or actively participates in zakat activities, starting from collecting zakat from muzaki to distributing it to mustahiq. Legal arrangements in Indonesia relating to the competence of amil zakat are very important in neglecting zakat funds and channeling them to mustahiq, but must be supported by the authorities. Islamic law considers the competence of amil zakat to be very urgent, with accountable amil. While the government is very competent in increasing Baznas income annually, supported also by the fatwa of the Indonesian Ulema Council (MUI) regarding the government's obligation to cut salaries for civil servants / ASNs to be more effective in raising zakat funds and Baznas will be more maximal in alleviating poverty and welfare of society and ummah as extension of the government to the welfare of the people.
\end{abstract}

Keywords: Zakat Collection, Civil Servants, Zakat Law, Islamic Law.

\begin{abstract}
Abstrak
Pada tahun 1998-1999 dan 2001-2003 dibentuk BAZNAS dengan Kepres sehingga tahun 2011 muncullah aturan pengolahan zakat yaitu Undang-Undang Nomor 23 tahun 2011. Melalui legal formal ini penulis akan mengkaji terminologi amil zakat menurut UndangUndang dan Hukum Islam. Amil zakat adalah orang yang terlibat atau ikut aktif dalam kegiatan pelaksanaan zakat, dimulai sejak mengumpulkan zakat dari muzaki sampai mendistribusikannya kepada mustahiq. Pengaturan hukum di Indonesia berkaitan dengan kopetensi amil zakat sangatlah penting dalam menghipun dana zakat dan menyalurkannya kepada mustahiq, namun harus didukung oleh pihak penguasa. Hukum Islam memandang kompetensi amil zakat sangat urgen, dengan akuntabel amil. Sedangkan pemerintah sangat berkompeten dalam meningkatkan pendapatan Baznas pertahunnya, didukung pula dengan fatwa Majelis Ulama Indonesia (MUI) tentang keharusan pemerintah memotong gaji bagi PNS/ASN akan lebih efektif dalam menghimpun dana zakat dan akan lebih maksimal Baznas dalam mengentaskan kemiskinan serta mensejahterakan masyarakat dan ummat sebagai perpanjangan tangan pemerintah mensejahterakan rakyat.
\end{abstract}

Kata Kunci : Pengumpulan Zakat, PNS, UU Zakat, Hukum Islam. 


\section{INTRODUCTION}

Zakat as a form of worship which prioritizes social values in addition to ritual messages, seems to have very long historical roots. It can be predicted as long as mankind itself (the generation of Adam as) or at least from the generation of several prophets of God Almighty and before the Prophet Muhammad, for example Prophet Musa, was obliged to give alms to the wealth of cattle, goats and camels. Nisab at that time (Anshori, 2010: 4). What is commonly known as the five arkan al-Islam (five pillars of Islam), namely creed, prayer, zakat, fasting, and pilgrimage are basically already recited since the time of the Prophet Adam, even if there are differences between generations of prophets with one another, then the inequality is more focused on matters that are formal symbolic and procedures that are tailored to the language of the people of the prophet concerned, rather than differences in the matters of substantial fundamentals (Hafhifuddin, 2012). The connection with the arguments according to revelation is in al-Baqarah: 43, at-Taubah: 34-35 and Maryam: 31.

The obligation of zakat at the time of the Prophet saw began in abd II Hijriah, at that time only the awareness of each individual, there was no official amil (Anshori, 2010). In the IX century, there was the term amil zakat designated by the State and paid for from the amil zakat (A.Karim, 2011; Hafhifuddin, 2012). After the death of the Prophet, it became the responsibility of Abu Bakr and got enemies of zakat dissidents (Tarigan, 2007). Technically the distribution follows the way of the Prophet (Al-Shaykh, 2014). After that, Umar prioritized people's welfare by empowering Baitul Maal (Tarigan, 2011).

Baitul Maal comes from the word bayt in Arabic which means home, and al-mal which has assets. Etymologically, baitul maal means khazinatul mal a place to collect or store property. As for terminologically, Baitul Maal is an institution or party that has a special task to handle all people's assets, both in the form of income and expenditure of the state. Baitul Maal can also be interpreted physically as a place to store and manage all kinds of assets that become State revenues (Sholahuddin, 2015). Whereas this modern and modern era is felt, almost all Islamic countries have used amil bodies to collect zakat and its distribution (Anshori, 2010; Hafhifuddin, 2012).

History records the development of amil zakat in Indonesia starting in 1968 issued by Minister of Religion Regulation Number 4 of 1968 concerning the Establishment of the Amil Zakat Agency and Minister of Religion Regulation Number 5 of 1968 concerning the 
Establishment of the Baitul Maal. The two PMAs have very close links because Baitul Maal functions as the recipient and container of zakat, and then is deposited to the amil zakat body to be distributed to the rightful. In 1984 the Minister of Religion issued Instruction No. 2 of 1984 dated March 3, 1984 concerning the Thousand Rupiah Infaq during the month of Ramadhan, the implementation of which was regulated in the Decree of the Director General of Islamic Bimas and Hajj Affairs Number 19/1984 dated April 30, 1984. The Minister of Religion 16/1989 concerning the Development of Zakat, Infaq and Shadaqah, which assigned all ranks of the Ministry of Religion to assist religious institutions that administer zakat, infaq and shadaqah to use zakat funds for Islamic education activities and others

In 1991 a Joint Decree of the Minister of Religion and Minister of Home Affairs was issued No. 29 and 47 of 1991 concerning Guidance of the Amil Zakat, Infaq and Shadaqah Agency which was then followed up with Minister of Religion Instruction Number 5 of 1991 concerning Guidelines for Technical Guidance of the Amil Zakat Agency, Infaq and Sadaqah and The Instruction of the Minister of Home Affairs Number 7 of 1998 concerning the General Guidance of the Amil Board of Zakat, Infaq and Shadaqah. In 1998-1999 and 2001-2003 BAZNAS was formed on the Presidential Decree (Baznas, 2016) until 2011 a law was regulated governing zakat processing in Law No. 23 of 2011 (Purbasari, 2015).

From the background above, the problem needs to be formulated is what is amil zakat and what is the competence of amil zakat according to Islamic Law and Law)?

\section{DISCUSSION}

\section{Amil Zakat}

The scholars provide various definitions of amil, including the following: 1). According to Imam Shafi'i amilun are people who are appointed to collect zakat from their owners (Asnaini, 2012: 54.). From this understanding, amil is the people in charge of collecting zakat. 2). According to Yusuf Qardhawi il amilun are all people who work in administrative equipment on zakat affairs, both in the matter of collecting, storing, recording, calculating and recording the entry of zakat and sharing with the mustahik (Qardhawi, terj., Harun, 2012: 545). 3). Regarding zakat collection officers, Hasbi chose the opinion of Abu Hanifah and Malik who stated that amilin was an officer who was given wages taken from the zakat collection according to the level of their labor (Shiddiqi, t.th: 209). 4). Amil zakat is all parties acting on the work related to the collection, storage, safekeeping, recording and distribution or distribution of zakat assets. 
(Kurnia, 2015: 142) So, amil zakat is the people involved or actively participating in zakat implementation activities starting from collecting zakat from muzaki to distributing it to mustahik. Amil's Legal Basis in the Koran (at-Taubah: 103 (Basyir, 1997: 76), at-Taubah: 60 (Shihab, 2012: 629 and al-Utsaimin, 2011: 298-299) and Sunnah and Fatwa MUI Number 8 In 2011 about Amil Zakat, namely: (MUI, MUI Fatwa Number 8 of 2011 concerning Amil Zakat, http://mui.or.id accessed on February 26, 2018):

Amil zakat is: a. A person or group of people appointed by the Government to manage the implementation of zakat worship; or b. A person or group of people formed by the community and authorized by the Government to manage the implementation of zakat.

Amil zakat must fulfill the following conditions: a). Muslim; b). Mukallaf (understanding and baligh); c). Trustful; d). Having knowledge about the laws of zakat and other matters related to the duty of amil zakat.

Amil zakat has the duty: a). Withdrawal / collection of zakat which includes compulsory data collection of zakat, determination of the obligatory object of zakat, the amount of zakat payment, the amount of zakat rates, and certain conditions for each object of obligatory zakat; b). Maintenance of zakat which includes inventory of assets, maintenance, and securing zakat assets; and c. Distribution of zakat which includes the distribution of zakat assets to arrive at the zakat mustahik properly and correctly, and includes reporting.

Basically, the operational costs of managing zakat are provided by the Government (ulil amr); In the event that operational costs are not funded by the Government, or provided by the Government but insufficient, then the operational costs of managing zakat which are the duty of amil are taken from zakat funds which are part of amil or from Fi Sabilillah within reasonable limits, or taken from outside funds zakat.

Activities to build zakat awareness such as advertisements can be funded from zakat funds which are part of amil or Fi Sabilillah within the reasonable, proportional and in accordance with the rules of Islamic law. Amil zakat which has received a salary from a state or private institution in its duties as amil is not entitled to receive a portion of the zakat fund which is part of amil. While amil zakat which does not get a salary from the state or private institution has the right to receive a part of the zakat fund which is part of amil as compensation on the basis of the principle of fai. Amil may not accept gifts from muzaki in relation to his duties as amil. Amil may not give gifts to muzaki that come from wealth of zakat (Nopiardo, 2016). 


\section{Authority of Amil Zakat According to Zakat Law}

Zakat management according to Law Number 23 Year 2011 is an activity of planning, implementing and coordinating supervision in the collection, distribution and utilization of zakat. These activities, one of which is the Amil Zakat Institution as stipulated in Article 17 of Law Number 23 Year 2011 concerning Management of Zakat. According to Sudirman, the Amil Zakat Institution is a zakat management institution formed by the community so that it does not have an affiliation with the Amil Zakat Agency (Sudirman, 2007), which incidentally was formed on the initiative of the government. Juridically, the definition of LAZ can be found in the explanation of Article 7 Paragraph (1) of Law Number 38 of 1999 concerning Management of Zakat. The amil zakat institution is seen as a zakat management institution that was fully formed on the initiative of the community and by the community (Law No. 38 of 1999). After this Law was amended, the definition of LAZ also experienced changes as stipulated in Article 1 point 8 of Act Number 23 of 2011 concerning Management of Zakat.

The Amil Zakat Institution, hereinafter abbreviated as LAZ, is an institution formed by a community that has the task of helping the collection, distribution and utilization of zakat (Law No. 23 of 2011). Through this definition, the role played by LAZ also changes, namely as a helper in the management of zakat in Indonesia. So according to the laws in Indonesia the competence of amil zakat is very important in regard to zakat funds, not only accepting zakat from the muzakki, it must also participate in reminding and enlightening and understanding the importance of tithe to help and cleanse property for the journalists to become the muzakki obedient (Ramadhita, 2011).

To improve the role and function of LAZ, four principles need to be developed, namely the principle of harmony, moral principles, management principles, and institutional principles. The principle of morality, pillars of faith, institutions, functions to increase public trust, especially muzakki to channel zakat, infaq, shadaqah to LAZ. While the management principle functions to empower mustahik, so that they can turn into muzakki in the future. hence the existence of LAZ and UPZ is proof that amil zakat is very competent in collecting zakat from the muzakki (Ramadhita, 2011; Purbasari, 2015).

\section{Amil Zakat Success According to Islamic Law}

Amil zakat competence in the opinion of the Islamic Ulama is (Nopiardo, 2016). The Syafi'i School states that zakat may be channeled through amil zakat formed by the government 
(imam), especially if the government is fair to its people. 2). According to the Hanafi School, it was stated that the best way to distribute zakat was done by muzaki, but if it still wanted to go through the amil zakat body, it was permissible and valid. (Rofiq, 2014: t.h.). 3). According to Hanabillah, it was stated that the circumcision of the muzaki handed over his own zakat, thus he was very sure, that his zakat arrived at his mustahik but if he gave it to the government, it was also permissible (jaiz). 4). According to Malikiyah, stating that if the priest is fair (remember, amil is an apparatus of the priest equal to the government), it is left to the priest and if it is not fair, it can be left to the mustahik himself (Santoso et al., 2014).

According to the scholars of the four schools of competence, amil zakat is only a solution and a suggestion if the government is fair. However, according to the author, this is if the relationship is to channel zakat, then the competence of amil zakat is very small, if it is related to zakat collection, which the journalists are reluctant to pay zakat, should the government intervene in collecting zakat funds as a form of State's welfare in public welfare. At least there is an urgency that paying zakat through official amil zakat is better fulfilled, and the purpose of welfare for the government will be helped. The urgency is: 1). In accordance with the qur'qn san sunnah texts; 2). To optimize the level of discipline of zakat payers; 3). To maintain the inferiority feelings of mustahik towards muzaki; 4). To achieve efficiency and effectiveness as well as targets in the utilization of zakat; 5). To show the symbol of Islam in terms of managing the economic potential of the people 6). To produce accurate muzaki and mustahik data (Nopiardo, 2016).

\section{Government Authority and Competence in Facilitating Zakat for PNS/AS}

Discourse Religion Minister Lukman Hakim Saifuddin said the plan to cut civil servant (PNS) salaries for zakat is not mandatory. The government only aims to facilitate civil servants to commit tithe. "There is no word of obligation, but the government facilitates Muslim civil servants to fulfill their obligations, namely cutting part of their income to pay tithe," Lukman said in his office, Central Jakarta, Wednesday, February 7, 2018.

Lukman said that not all employees are obliged to pay income zakat. Before applying the deduction, the employee will be asked for his approval. Later, any civil servant who enters mandatory zakat requirements will be recorded. Determination will be carried out in accordance with Islamic law. As for those who will collect and manage zakat from civil servants are the 
National Amil Zakat Agency (Baznas) and other amil zakat bodies. Lukman said that the collected zakat will be used for various interests of the Indonesian people, not just for Muslims.

According to Lukman, this plan was based on the awareness of the huge potential of zakat in Indonesia. He said, if this plan is successful, it is estimated that IDR 10 trillion will be raised per year. "It can be allocated for education, for example building Islamic boarding schools, madrasas, hospitals, helping economic development, as well as victims of natural disasters," he said (Tempo. Wednesday, 7 February 2018 16:51 WIB).

The statement of the minister of religion was welcomed by the MUI, Deputy Secretary General of the Indonesian Ulema Council (MUI) Amirsyah Tambunan said the agency supported the government's proposal to withdraw zakat 2.5 percent of the salaries of civil servants (PNS) who are Muslim. Amirsyah also appreciates if the policy is properly implemented. "What is important is the benefit of the people and the nation," Amirsyah said when contacted by Tempo on Tuesday, February 6, 2018. According to Amirsyah, taking zakat can be done in various sectors. Not only civil servants, zakat can also be withdrawn from the police or the Indonesian National Army (TNI) for example. Because, zakat is obligatory for Muslims.

Therefore, according to Amirsyah, optimizing the increase in zakat is important to implement. Besides being obligatory in the Islamic religion, taking zakat is one step to alleviate poverty. Even so, said Amirsyah, the government needs to think about how to optimize it. The cuts in civil servants' salaries are considered not problematic provided the rules are clear. For example, the government specifies whether all civil servants are obliged to give zakat or only those who are able and fulfill the requirements according to Muslim teachings. "Study must be done first. Try to discuss with stakeholders, there are MUIs or other mass organizations (community organizations), so that the study can be understood and accepted by all parties, "Amirsyah said. Religious Minister Lukman Hakim Saifuddin said that he was preparing the rules regarding zakat collection for civil servants. The zakat comes from deductions from salaries of civil servants who are Muslim at 2.5 percent. "We are preparing a presidential decree (presidential decree) for special zakat collection and this only applies to ASN or Muslim civil servants," he said. Withholding only applies to Muslims. Because, only Muslims have the obligation to pay zakat. However, according to Lukman, deductions from salaries for zakat are not mandatory. Civil servants or state civil servants (ASN) may raise objections if they are not willing to deduct their salary (Tempo. Wednesday, 7 February 2018 16:51 WIB). 
But the discourse of the Minister of Religion and MUI was denied by members of the Republic of Indonesia Ombudsman in the field of Religion, Social and Culture Ahmad Su'adi, assessing the plan to withdraw 2.5 percent of Muslim civil servants' salaries for zakat has the potential for maladministration. If the government implements the idea, a violation has occurred. "Zakat is a private matter. So the state must not interfere, let alone withdraw zakat into the government," Ahmad said when contacted by Tempo, Tuesday, February 6, 2018. According to Ahmad, the government should fail to carry out the plan. Because, zakat worship is a private matter, so the state should not interfere with the matter. Moreover, said Ahmad, the management of wrong zakat results in major sins. For example, there is fraud or corruption of zakat funds. "If it happens, the government does what is not supposed to or even prohibited. But this (salary withdrawal) is just a plan," Ahmad said. If the government still wants to withdraw zakat from Muslim civil servants, in the law it is necessary to state the difference between who is mustahik or is entitled to receive zakat and who is the zakat provider.

Ahmad said that the withdrawal of zakat from civil servant salaries had occurred in East Lombok around 2006 or 2007. Initially, the Regional People's Representatives Council and the local regent made a policy similar to the collection of zakat from civil servants. But civil servants feel disturbed and exploited. So they rallied massively. The majority of protesters are lowerranking civil servants. According to Ahmad, it is possible that this will happen again when the government officially collects zakat from Muslim civil servants. Previously, Minister of Religion Lukman Hakim Saifuddin said that he was preparing the rules regarding zakat collection for civil servants. The zakat comes from deductions from salaries of civil servants who are Muslim at 2.5 percent. "We are preparing a presidential decree (presidential decree) for special zakat collection and this only applies to ASN (state civil apparatus) or Muslim civil servants," he said. Cutting, he said, only applies to Muslims, because only Muslims have an obligation However, according to Lukman, salary deductions for zakat are not compulsory, civil servants or ASNs may object if they are not willing to deduct their salary (Tempo. Wednesday, February 7, 2018 16:51 WIB).

According to the authors of the three institutions in the country, namely the minister of religion, the ulama and ombudsman assemblies, there is truth in it, but in Islamic law according to the author, the Ministry of Religion and the MUI are far more appropriate to the present situation, many rich people are reluctant to pay zakat, even the juridical foundation had existed since the Prophet and Abu Bakr, Based on al-Hakim which comes from Jabir, that the Prophet 
Muhammad SAW ordered to take zakat with one sha' of date palm. At that time, a man came to the Prophet while bringing bad quality date palm. Then, this verse (Al-Baqarah 267) was revealed by Allah as a guidance for His believers to take zakat from the best yields and the best quality of goods (Maulida, 2019).

This situation is very appropriate according to the author, that the government with the intention of helping Baznas to collect zakat, and facilitate the muzakki in fulfilling their obligations without having to bother distributing to mustahiq. Dissolution of the role and competence of the government in accordance with the opinions of the Maliki school, in this case is more precise and more useful. So the review of the Maqashid Shariah government competency in cutting civil servants / ASN salaries is very difficult for the community. While the ombudsman's opinion can be ignored, if the management is handed over to Baznas, then the ombudsman statment is nothing to worry about. While the government's desire is only to help Baznas hard work in collecting zakat for the Muslim ummah, this is a good intention, it should not be ignored and must be supported.

\section{CONCLUSION}

Amil zakat is people who are involved or actively participate in zakat implementation activities starting from collecting zakat from muzaki to distributing it to mustahik. According to Indonesian law, the authority and competence of amil zakat are very important in neglecting zakat funds and channeling them to mustahiq, but the dominant collection must be supported by the authorities. According to Islamic law the authority and competence of amil zakat are very urgent too, especially if the amil is fair and transparent. While the government's competency in increasing Baznas revenue in collecting zakat is very urgent, especially if the MUI can issue a fatwa to cut salaries for PNS / ASN to be more effective in collecting zakat and Baznas will be more maximal in alleviating poverty and welfare of society, ummah and people.

\section{BIBLIOGRAPHY}

\section{(Book)}

A.Karim, Adiwarman. (2011). History of Thought of Islamic Economics. Jakarta: The International Institute of Islamic Thought (IIIT).

Al-Shaykh, Yasin Ibrahim. (2014). Zakat Improves Fasting for Cleaning Treasure. Bandung: Publisher Marja. 
Al-Utsaimin, Muhammad bin Shalih. (2011). Contemporary Zakat Jurisprudence, Surakarta: AlQowam.

Anshori, Abdul Ghofur. (2010). Law and Empowerment of Zakat, Synergy Efforts to Obligate Zakat and Taxes in Indonesia. Yokyakarta, Pilar Media.

Asnaini, (2012). Zakat in the perspective of Islamic Law. Yogyakarta: Student Library.

Basyir, Ahmad Azhar. (2007). Zakat Law. Yogyakarta: Muhammadiyah Central Leadership Council.

Hafhifuddin, Didin. (2012). Zakat in the Economy. Jakarta: Modern, Gema Insani.

Hafidhuddin, Didin. (2012). Zakat in the Modern Economy. Jakarta: Gema Insani.

Kurnia, Hikmat and Hidayat, A. (2015). Smart Guide of Zakat, Treasure of Blessings, Reward Increases Plus The Right Way \& Easy to Calculate Zakat. Jakarta: Qultum Media.

M.Sholahuddin. (2015). Baitul Maal is a Sharia Currency standard, Paper of the Indonesian Economist Association. Proceedings of the International Seminar on Islamic Economics As A Solution, Medan, September 18-19.

Qardhawi, Yusuf. (2012). Fiqh Zakat, Indonesian edition of Zakat Law. translated by Salman Harun, Didin Hafidhuddin and Hasanuddin, Jakarta: PT. Litera Antar Nusa Library and Amil Zakat and Infak / Shodaqoh Agency DKI Jakarta.

Rofiq, Ahmad. (2014). Contextual Fiqh. From Normative To Social Meaning. Semarang, Student Library.

Santoso, Fattah et al. (2014). Islamic Studies 3. Surakarta: Institute of Islamic Studies.

Shiddiqi, Nouruzzaman t.th. Indonesian Fiqh: Ideas and Ideas, Yogyakarta: Student Center.

Shihab, M. Quraish. (2012). Interpretation of Al-Mishbah: Message, Impression, and Harmony of the Qur'an, Jakarta: Lentera Hati.

Sudirman. (2007). Zakat in Pusaran Arus Modernitas. Malang: UIN-Malang Press.

Tarigan, Azhari Akmal. (2011). Fundamentals of Islamic Economics. Bandung: Citapustaka Media.

\section{(Journal Article)}

Nopiardo, Widi. (2016) Urgency of Zakat Through Amil in the View of Islamic Economics. Syari'ah Scientific Journal, Volume 15, Number 1, January-June. 
Maulida, S. (2019). Zaqah Profession, Oil Palm Plants, and Coal. Indonesian Interdisciplinary Journal of Sharia Economics (IIJSE), 1(2), 41-52. https://doi.org/10.31538/iijse.v1i2.195

Purbasari, Indah. (2015). Management of Zakat by Amil Zakat Agencies and Institutions in Surabaya and Gresik. Mimbar Hukum Journal Volume 27, Number 1, February.

Ramadhita. (2011). Optimizing the Role of Amil Zakat Institutions in Social Life. Jurisdictie, Journal of Law and Sharia, Volume 3, Number 1, June.

\section{(Website)}

Baznas, National Zakat Amil Agency, Thursday, December 8, 2016.

Tempo. Co, MUI Supports Plans to Cut PNS Salaries for Zakat. https://nasional.tempo.co/read/1057849/mui-dukung-rencana-pemotongan-gaji-pnsuntuk-zakat.diakses27 February 2018.

Tempo. Co, Minister of Religion: Cutting Salary of Civil Servants for Alms Not Required. https: //nasional.tempo.co/read/1058375/menteri-agama-pemotongan-gaji-pns-untuk-zakattidak-wajib.diakses27 February 2018.

Tempo. Co, Ombudsman: Zakah Collection of PNS Muslim Potential Mal administration. https: //nasional.tempo.co/read/1058086/ombudsman-pungutan-zakat-pns-muslim-berpotensimaladministrasi.diakses27February2018.

\section{(Government Institution Documents)}

State of 1999 Number 164 Additional State Gazette Number 3885.

Law Number 23 of 2011 concerning Management of Zakat of the State Gazette of 2011 Number 115.

Law Number 38 Year 1999 concerning Management of Zakat Sheet. 